\title{
Land Use and Landscape Pattern Changes in Chongqing Liangjiang New District
}

\author{
Jin Luo ${ }^{1}$, Yong Liu ${ }^{1} \&$ Cheng Wang ${ }^{1}$ \\ ${ }^{1}$ School of Resources and Environment, Southwest University, Chongqing Municipality, China \\ Correspondence: Jin Luo, School of Resources and Environment, Southwest University, Chongqing Municipality, \\ 400716, China. Tel: 86-1-582-384-4586. E-mail: 280554827@qq.com
}

Received: May 20, 2012 Accepted: June 26, 2012 Online Published: October 18, 2012

doi:10.5539/par.v1n1p42 URL: http://dx.doi.org/10.5539/par.v1n1p42

\begin{abstract}
Taking Chongqing Liangjiang new district within second-ring road as researching area, analyzed its land use and landscape pattern changes during 1988, 2001 and 2010. After utilizing ENVI to do the remote sensing images interpretation, land use changes were described in conversion matrix. Method of FRAGSTATS was utilized to calculate the special landscape indices, which included patch density $(P D)$, largest patch index $(L P I)$, land shape index $(L S I)$, contagion $(C O N T A G)$, landscape division index (DIVISION), aggregation index $(A I)$. Results show Land use types change from farmland to urban mostly during 2001 to 2010; PD, LPI and $L S I$ drop down, the other three have increasing tendency. Land use and landscape pattern associate with each other, Urbanization featured with human activities, causes landscape changes, besides, preferential policies of Conversion of cropland to forest, urban planning and the typical "Three Reforms" in Chongqing boosts land cover changes too.
\end{abstract}

Keywords: landscape pattern, land use, urbanization, Chongqing Liangjiang new district

\section{Introduction}

Recently, Chinese cities have experienced rapid population growth and continuous expansion, resulting in considerable and sustained demand for land resources. Meanwhile, urbanization has imposed significant pressure on the land-use structure, terrestrial and aquatic ecosystems, of these areas (Liu et al, 2007). The changes in land use caused by urbanization greatly affect the structure and function of urban ecosystems (Zhou \& Cadenasso, 2011). Land-use structure was associated well with landscape pattern in structural elements, although the quantification of landscape structure is not a new topic (Forman \& Godron, 1986; O'Neill, 1988), this field is still evolving due to the ongoing developments in geo information technology (Gardner, Lookingbill, Townsend \& Epprecht, 2009; Riitters, Vogt, Soille \& Estreguil, 2009; Saura \& Castro, 2007). With development of modern cities, urban landscape becomes one of the fastest variable patterns, from the aspect of landscape patterns to review urbanization attracts more and more attention. However, most theories of urban landscape patterns changes focus on plaint cities, different terrains have huge impacts on landscape structures (Ispikoudis, Lyrintzis \& Kyriakakis, 1993; Hobbs, 1993; Pignatti, 1993), which means hilly cities show uniqueness in land use and landscape patterns changes, its features need special analysis.

Chongqing experienced rapid economic development since direct jurisdiction of the Central Government. Especially, after Three Gorges being set up, the Urban and Rural Harmonious Experimental District was founded in Chongqing, along with which, the first inland-bonded-port area established in northern main urban district, until 2009, the completed high-way took Chongqing towards the second-ring new era. Following Shanghai Pudong New Area and Tianjin New Coastal Region, Liangjiang New District of Chongqing becomes the third national Special Economic Zones. Founded in June. $18^{\text {th }}, 2010$, it is given certain of special policies, especially the tax policy with appropriate special discount $(15 \%)$, which attracts some international factories like HP, Foxconn and Ford ( Su, Yang \& Liu, 2011).

Liangjiang New District (within the second-ring road) is chosen to be our researching area. The fast development results in rapid land use changes as well as the landscape pattern changes. Extracted the needed information of Liangjiang New District in 1988, 2001 and 2010 to demonstrate the effects of urbanization on land use and land pattern changes, in addition, discuss the driving forces. 


\section{Methods}

\subsection{Study Site}

In order to combine the approaches of landscape and land-use changes in an exemplary manner, majority area of Liangjiang New District of Chongqing was selected for the investigation, approximately $733.5 \mathrm{~km}^{2}$ in size.

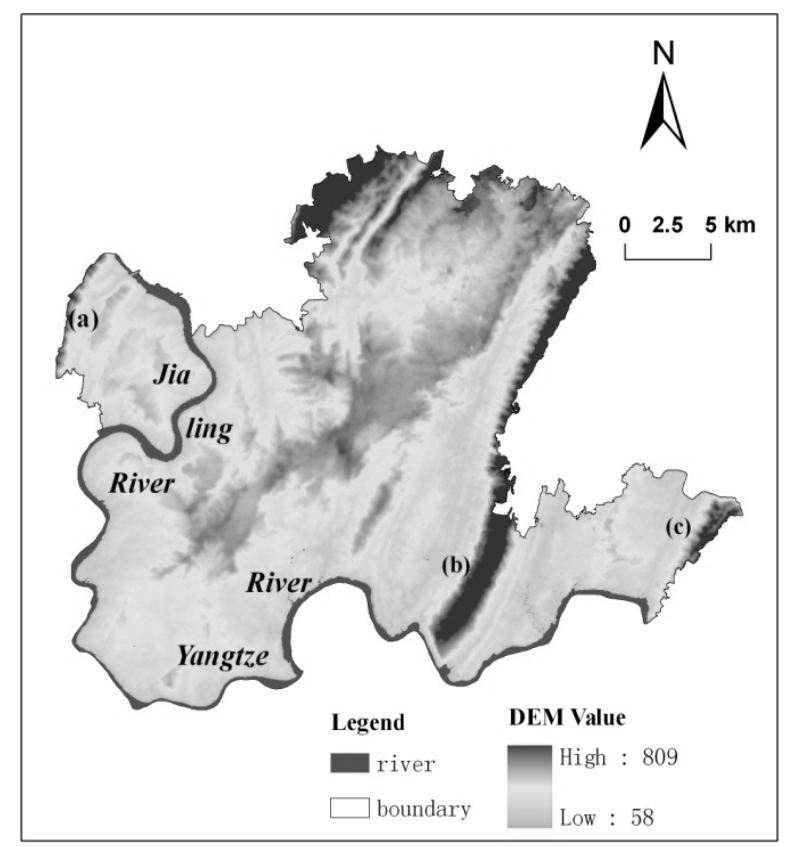

Figure 1. Liangjiang New District within the second-ring road

Description: (a) Zhongliang Mountain, (b) Tongluo Mountain, (c) Mingyue Mountain

As Figure. 1 shows, it spans Zhongliang Mountain, Tongluo Mountain and Mingyue Mountain, above Yangtze River and Jialing River (Figure 1). It traverses a hilly-urban-water-hilly gradient from the west to the east, through high elevation area to plaint valleys in the middle section. Land cover features are typical of those in different terrains, including vegetation covers such as trees and grass, farmlands and urban environments, as well as the water. These test areas was chosen because it is inside the second-ring road, in which preferential policies implemented in priority. With rapid development, land use types and landscape pattern changes more quickly, the changes during three researching periods can be much obvious to analysis.

\subsection{Methods}

\subsubsection{Data Sources and Progressing}

We depend on the Landsat TM/ETM+ images with 30m resolution in three periods: 1988, 2001 and 2010 ( line: 128, row: 39,40), the second national land investigation map of Chongqing (2009).

In the first place, three periods images needed correction, fusion and clipping, after which, classification system was produced, concerning about the resolution, we chose four classes system: farmland, urban, hill, water.

The second national land investigation map of Chongqing was applied to extract the boundary of study site, as well as the hill, water and urban area in 2009. Since one year development will have no big changes, we transfer the area of urban, hill and river into region of interest (ROI) in Envi4.6, then subset the data by ROI, the left data contains less such land use types, but still needs reclassification. After choosing typical pixels, maximum likelihood was utilized to reclassify.

Finally, combine the classes based on our class system to obtain the data in three periods. In order to check our precision, 61 random points was chosen as samples, with help of Google Earth, the precision in 2010 reached $91.8 \%$, Kappa index was 0.76 , which can basically satisfy our demand. 


\subsubsection{Measures of Landscape Indices}

Landscape pattern indices are concentration of landscape information, which can reflect features of construction and spatial allocation. Since landscape pattern can be divided into three gradients according to different matrices: class, patch and landscape ( $\mathrm{Wu}, 2007)$. Numerous metrics have been developed to quantify the composition and conFigureuration of land cover features (Gustafson, 1998; McGarigal, Cushman \& Neel, 2002), they have been used to measure a region's landscape change through time (Dunn, Sharpe \& Guntenspergen, 1990; Delong \& Tanner, 1996; Reed, 1996). In order to investigate and compare the before-and-after landscape patterns, we choose the following landscape pattern indices: patch density $(P D)$, largest patch index $(L P I)$, land shape index $(L S I)$, contagion $(C O N T A G)$, landscape division index $(D I V I S I O N)$, aggregation index $(A I)$. With 8 cells as patch neighbors, Fragstats 3.3 were applied to calculate the landscape pattern indices.

(1) $P D$ equals the number of patches in the landscapes, divided by total landscape area $\left(\mathrm{m}^{2}\right)$, multiplied by 10000 and 100 (to convert to 100 hectares). It is a limited, but fundamental, aspect of landscape pattern, which shows fragmentation of the patches.

$$
P D=\frac{N}{A}(10,000)(100)
$$

Where $N$ is the total number of patches in the landscape, $A$ is the total landscape area $\left(\mathrm{m}^{2}\right) . P D$ is ultimately constrained by the grain size of the raster image, because the maximum $P D$ is attained where every cell is separate patch.

(2) LPI equals the area $\left(\mathrm{m}^{2}\right)$ of the largest patch of the corresponding patch type divided by total landscape area $\left(\mathrm{m}^{2}\right)$, multiplied by 10000 and 100 (to convert to 100 hectares); in other words, it is the percentage of the landscape comprised by the largest patch.

$$
L P I=\frac{\max _{j=1}^{n}\left(a_{i j}\right)}{A}(100)
$$

Where $a_{i j}$ is the area $\left(\mathrm{m}^{2}\right)$ of patch $i j ; A$ is the total landscape area $\left(\mathrm{m}^{2}\right) . L P I$ approaches 0 when the largest patch of the corresponding patch type is increasingly small. $L P I=100$ when the entire landscape consists of a single patch of the corresponding patch type; that is, when the largest large patch comprises $100 \%$ of the landscape.

(3) LSI equals the total length of edge in the landscape, given in number of cell surfaces, divided by the minimum total length of edge possible, also given in number of cell surfaces, which is achieved when the landscape consists of a single patch.

$$
L S I=\frac{E}{\min E}
$$

Where $E$ is total length of edge in landscape in terms of number of cell surfaces; includes all landscape boundary and background edge segments; min $\mathrm{E}$ is minimum total length of edge in landscape in terms of number of cell surfaces. $L S I \geq 1$ without limit, it increases as landscape shape becomes more irregular or as the length of edge within the landscape increases; $L S I=1$ when the landscape consists of a single square patch.

(4) CONTAG is the observed contagion over the maximum possible contagion for the given number of patch types.

$$
\text { CONTAG }=\left[1+\frac{\sum_{i=1}^{m} \sum_{k=1}^{m}\left[\left(P_{i}\right)\left(\frac{g_{i k}}{\sum_{i=1}^{m} g_{i k}}\right)\right] \times\left[\ln \left(P_{i}\right)\left(\frac{g_{i k}}{\sum_{i=1}^{m} g_{i k}}\right)\right]}{2 \ln (m)}\right]
$$

Where $P_{i}$ is proportion of the landscape occupied by patch type (class) $i$; $g_{i k}$ is number of adjacencies between pixels of patch types $i$ and $k$ based on the double-count method; m is number of patch types present in the landscape, including the landscape border if present. $0<C O N T A G \leq 100$, it approaches 0 when the patch types are maximally disaggregated and interspersed; $C O N T A G=100$ when all patch types are maximally aggregated.

(5) DIVISION is based on the cumulative patch area distribution and is interpreted as the probability that two randomly chosen pixels in the landscape are not situated in the same patch.

$$
\text { DIVISION }=\left[1-\sum_{i=1}^{m} \sum_{j=1}^{m}\left(\frac{a_{i j}}{A}\right)^{2}\right]
$$

Where $a_{i j}$ is area $\left(\mathrm{m}^{2}\right)$ of patch $i j ; A$ is total landscape area $\left(\mathrm{m}^{2}\right) .0 \leq$ DIVISION $<1$, DIVISION $=0$, when the 
landscape consists of single patch. DIVISION is achieves its maximum value when the landscape is maximally subdivided; that is, when every cell is a separate patch.

\subsubsection{Land Use Conversion Matrix}

Land use change detection analysis can be applied directly to satellite imagery ( $\mathrm{Lu}$, Morineau \& Piron, 2003). After obtaining post-classification images, via change detection technique (Van Oort, 2007), we got two matrixes of transitions between land categories (Manandhar, Odeh \& Pontius, 2010), the first is land use changes between 1988 to 2001, the second is from 2001 to 2010 .

Applied ENVI 4.6 to do change detection, exported the information and selected "area" as index to do further analysis. Next, compared the conversion matrixes, and concluded differences in the above two periods.

\section{Results and Analysis}

\subsection{Landscape Indices Changes}

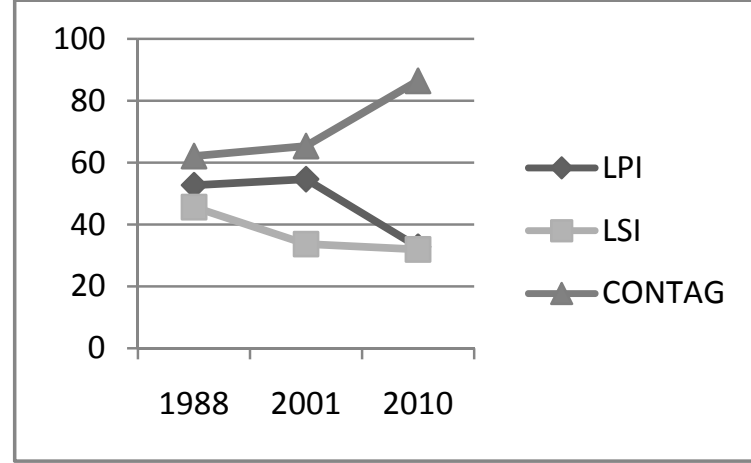

(a) Changes of LPI, LSI and CONTAG

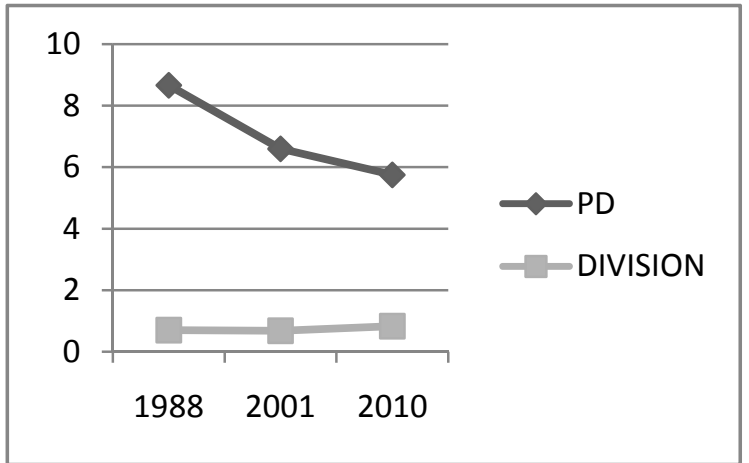

(b) Changes of $P D$ and DIVISION

Figure 2. Changes of landscape indices

After calculating landscape indices in corresponding researching period, the changes of landscape indices were concluded as Figure.2. Except for DIVISION kept still, the other indices changes a lot. CONTAG increases dramatically, with values increase slightly from 62.12 to approximately 65 , and then rises beyond 80 . Conversely, LSI has the opposite tendency, which falls by almost 10 in the first researching period, follows by a further slight decrease to 31.94. LSI remains slight increase before dipping sharply to approximately 30 in 2010 . Compared to the above indices, $P D$ and DIVISION have less distinguished changes (b), whose values are below 10 in general. $P D$ shows a constant decrease with a big drop from to 6.60 in 2001, and then a further fall to 5.75 in 2010.

\subsection{Land Use Changes between 1988 to 2001}

Concerning the resolution of the used Lands at $\mathrm{TM} / \mathrm{ETM}+$ images, we divided the primary images into four classes: urban, hill, water and farmland. Conversion matrix was made to investigate changes among the four land use types from 1988 to 2001, 2001 to 2010 .

Table 1. Land use changes conversion matrix from 1988 to $2001\left(\mathrm{~km}^{2}\right)$

\begin{tabular}{cccccc}
\hline \multirow{2}{*}{\multicolumn{2}{c}{ Land use types }} & \multicolumn{3}{c}{1988} \\
\cline { 3 - 6 } & & Urban & Hill & Water & Farmland \\
\hline \multirow{3}{*}{2001} & Urban & 17.29 & 0.01 & 7.30 & 28.03 \\
& Hill & 0.01 & 108.42 & 0.07 & 0.33 \\
& Water & 0.70 & 0.03 & 29.69 & 2.96 \\
& Farmland & 2.63 & 0.63 & 43.62 & 491.97 \\
\hline
\end{tabular}

Generally, forest changes the least during 1988 to 2001 (Table.1), most of which $\left(0.63 \mathrm{~km}^{2}\right)$ transfers to farmland, whilst, $0.33 \mathrm{~km} 2$ farmland turns to be forest at the same period, hence, the total area of forest keeps almost 
unchanged on the whole. At this period, Chongqing had not experienced rapid urbanization yet, its urban area maintained slightly changes along with farmland. Surprisingly, the sharpest changes occur between water and farmland, $43.62 \mathrm{~km}^{2}$ water transfers to farmland, which has exceeded the unchanged water area. Since 1988, Chongqing suffered from the huge flood, after which, Yangtze River and Jialing River has swelled, reflected by RS images, the neighboring area contains more water. Majority area especially farmland in Liangjiang New District is along the two rivers, consequently, several patches were covered by flood water. When years pass by, such patches were uncovered and changed from water area to farmland. Obviously, with more farmers cultivate land, the area of farmland increases too.

\subsection{Land Use Changes between 2001 to 2010}

Compared with the former researching period, urbanization has a bigger impact on land use changes in latter period, the most distinguished changes are between urban area and farmland.

Table 2. Land use changes conversion matrix from 2001 to $2010\left(\mathrm{~km}^{2}\right)$

\begin{tabular}{cccccc}
\hline \multirow{2}{*}{ Land use types } & \multicolumn{3}{c}{2001} \\
\cline { 2 - 5 } & & Urban & Hill & Water & Farmland \\
\hline \multirow{2}{*}{2010} & Urban & 49.80 & 0.26 & 2.80 & 147.84 \\
& Hill & 0.81 & 103.05 & 0.13 & 20.85 \\
& Water & 0.17 & 0.68 & 27.82 & 1.00 \\
& Farmland & 1.85 & 4.77 & 2.64 & 369.06 \\
\hline
\end{tabular}

As shown in Table.2, from 2001 to $2010,147.84 \mathrm{~km}^{2}$ of farmland becomes urban area, which almost reaches $50 \%$ of the maintained one. According to urban planning, Liangjiang New District will be the newly economic center of Chongqing. Consists of financial center in the south, exhibition center in the airport in the north, dutiable free port in the east, Liangjiang New District attracts dynamic investments to boost its industries, in such condition, urban expansion develops rapidly after 2001., Affected by the nation policy of Conversion of Cropland to Forest, 20.85 $\mathrm{km}^{2}$ farmland transfers to forest, which keeps the amount of ecological area stable or even increasing.

\section{Discussion}

\subsection{Urbanization Effects}
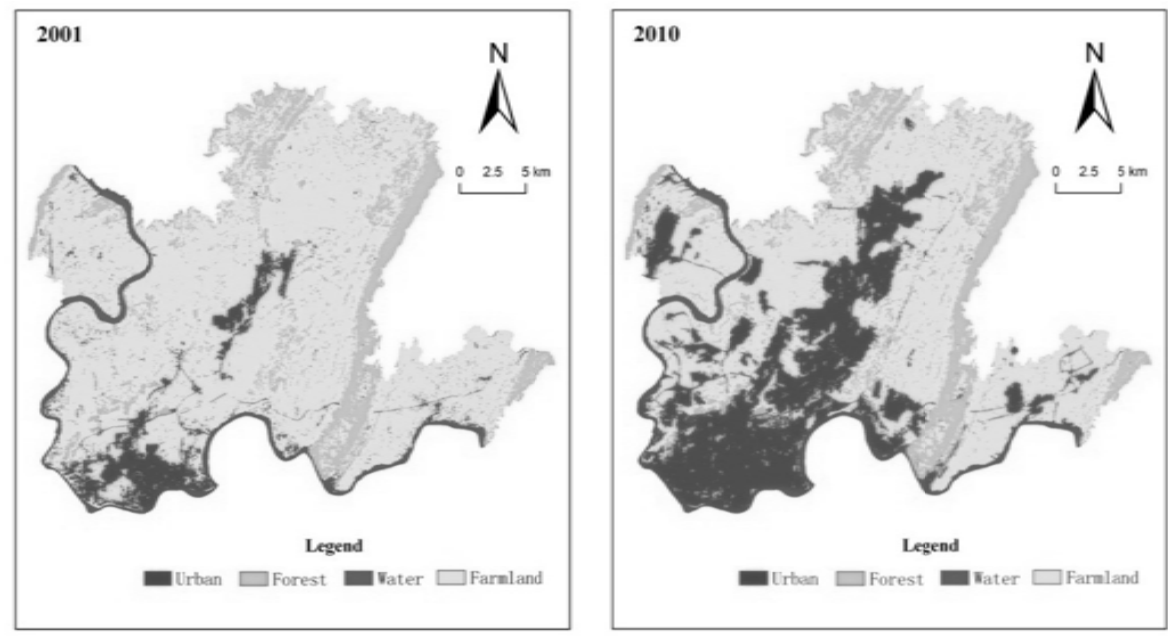

Figure 3. Land use cover of study area in 2001 and 2010

Our results demonstrate that both land use changes and landscape indices changes are much more significant from 2001 to 2010, when urban area has replaced agrarian covers mostly. Our further study concentrates on 
influence of urbanization on landscape patterns.

Constrained by natural resources (mountains and river), Urban expansion in this period is around valley along Yangtze River and Jialing River, especially Yangtze River, where plenty of urban area has existed in 2001 (Figure.3). Linear expansion shows the development of transportation, since high-way project was almost completed till 2010, the second-ring road era starts, and urban sprawl in this period is featured with aggregation along traffic lines.

Changes of $P D, L S I$ and $C O N T$ indicate the effect of urbanization. Firstly, Farmland is much fragmented than urban area, which means more small patches contained in former imagery, value of $P D$ drops when some arable land transfers to urban and becomes part of CBD. Additionally, with less independent patches, urban patches are relatively regular, which results in lower $L S I$. It is obvious that, urban develops only when population, industries or investments concentrated, consequently, CONT accelerates when urbanization develops with a fast speed.

\subsection{Driving Forces of Policies}

\subsubsection{Conversion of Cropland to Forest}

Since 2000, China has implemented The Strategy of Large-Scale Western Development, numbers of western cities especially Chongqing enjoys several preferential policies.

Concerning about deteriorated environment in such areas, Conversion of Cropland to Forest is carried out, based on which, the poor land with low output should be improved and then transfer to be forest. Responses of the policy can be reflected by land use changes from farmland to forest. Studies elsewhere confirm this trend, for example in Galicia (Spain), Siena (Italy) or Tuscany (Italy), where the abandonment of agricultural activities has been accompanied by an increase in forests area (Calvo-Iglesias, 2006; Agnoletti, 2007; Geri, 2010).

\subsubsection{Urban Planning}

According to urban master planning, the available urban area in Liangjiang New District is $550 \mathrm{~km}^{2}$, the remained land covers are water and ecological districts that cannot be developed. The old cities reconstruction of southern part started in 2002; by 2005, Chongqing Theater was commenced as well as the road construction; since 2009, the commercial street was set up in central Liangjiang New District, with a target of making Chongqing to be the financial center in the upper and middle Yangtze River, Liangjiang New District is increasingly indispensable. As a result, urban expansion accelerates with a high speed and land covers change a lot during 10 years.

\subsection{3 "Three Reforms"}

Since the party put forward the strictest arable land protection, like the dynamic equilibrium of the whole land, it means urban development should guarantee to offer the same amount of farmland before occupying arable land. With rapid urbanization, Liangjiang New District has a serious of reform to solve this problem, including land quota, household registry reform and construction of public rental housing.

The first land quota was verified in February 2010, which initiates a creative road for obtaining land index (Yang, 2011). It contains four steps: land reclamation, acceptance, transaction and using the land quota, before requisition, equal amounts of arable land in other districts of Chongqing will be reclaimed, hence, it makes up for the deficiency of Requisition-compensation Balance and keeps the dynamic equilibrium of the whole land in Chongqing municipal city.

Development of Liangjiang New District supplies considerable job opportunities for immigrants, most of who comes from countryside. In order to absorb such new employees and make them to be citizens, household registry reform was implemented since August 2010. Before migration, farmers are given compensation (67000 Yuan on average) for releasing their residential land, arable land or forest. It encourages rural residents especially the youths to work and live in Liangjiang New District.

Accompany with urbanization, housing price increase much more rapidly, which greaten pressure to citizens, for new immigrants from rural area, living comes first. In this situation, Chongqing carries out the public renting house in 20 residential areas, 9 of which are founded in Liangjiang New District. Differentiated from other modern cities like Beijing, Shanghai, public renting house in Chongqing has no household registry limits. Once works in Chongqing stably, singles with monthly salary lower than 2000 Yuan or families with 3000 minus monthly can apply for public renting house. Since such rents only accounts for $60 \%$ of ordinary ones, it attracts more people to work and live in Chongqing. 


\section{Conclusions}

The landscapes of Liangiiang New District within second-ring road are more dynamic from 2001 to 2010 than the former period. In details, CONTAG increases significantly, PD, LPI and LSI drop down a lot, DIVISION remains steady. Correspondently, Land use changes mostly occur between farmland and urban area, since urban area rises, several fragmented patches aggregate together and becomes more concentrated, which in turn, can be reflected by landscape patterns.

Urbanization and preferential policies boost landscape and land use changes. Constrained by natural environments, urban sprawl in Liangjiang New District is almost along the Yangtze River and Jialing River, between Zhongliang Mountain and Tongluo Mountain, which results in higher aggregation degree.

Conversion of cropland to forest policy explains the increases of forest in the latter period. With guidance of urban master planning, urban expansion in Liangjiang New District accelerates since 2001. "Three Reforms" in Chongqing ensures urban areas rises: land quota trading makes constructed land-use index legally transforms from rural to urban, after that, moving farmer-immigrants to "Liangjiang New District" with help of residence reform, additionally, public renting house offers low renting fee for their stable lives.

Future research will involve the quantitative analysis on relationship between landscape indices and land use changes; the analysis of land cover maps and socioeconomic data to determine the main factors driving landscape dynamics.

\section{Acknowledgements}

This research was supported by the National Natural Science Foundation (No. 41101568) and the Post doctor fund (NO.20100470805). We would like to express our gratitude to the anonymous reviewers.

\section{References}

Agnoletti, M. (2007). The degradation of traditional landscape in a mountain area of Tuscany during the 19th and 20th centuries: implications for biodiversity and sustainable management. Forest Ecology and Management, 249, 5-17. http://dx.doi.org/10.1016/j.foreco.2007.05.032

Calvo-Iglesias, M. S., Fra-Paleo, U., Crecente-Maseda, R., \& Diaz-Varela, R. A. (2006). Directions of change in land cover and landscape patterns from 1957 to 2000 in agricultural landscapes in NW Spain. Environmental Management, 38, 921-933. http://dx.doi.org/10.1007/s00267-005-0276-1

Dunn, C. P., Sharpe, D. M., Guntenspergen, G. R., Stearns, F., \& Yang, Z. (1990). Methods for analyzing temporal changes in landscape pattern. In Turner, M. G., \& Gardner, R. H. (Eds.), Quantitative Methods in Landscape Ecology (pp. 173-198). New York, NY: Springer-Verlag.

Delong, S. C., \& Tanner, D. (1996). Managing the pattern of forest harvest: lessons from wildfire. Biodiversity Conserve, 5(10), 1191-1205. http://dx.doi.org/10.1007/BF00051571

Forman, R. T. T., \& Godron, M. (1986). Landscape ecology. New York: John Wiley and Sons.

Gardner, R. H., Lookingbill, T. R., Townsend, P. A., \& Ferrari, J. (2008). A new approach for rescaling land cover data. Landscape Ecology, 23, 513-526. http://dx.doi.org/10.1007/s10980-008-9213-z

Gustafson, E. J. (1998). Quantifying landscape spatial pattern: What is the state of the art? Ecosystems, 1, 143-156. http://dx.doi.org/10.1007/s100219900011

Geri, F., Rocchini, D., \& Chiarucci, A. (2010). Landscape metrics and topographical determinants of large-scale forest dynamics in a Mediterranean landscape. Landscape and Urban Planning, 95, 46-53. http://dx.doi.org/10.1016/j.landurbplan.2009.12.001

Hobbs, R. J. (1993). Integrated landscape ecology: A Western Australian perspective. Biological Conservation, 64(3), 231-238. http://dx.doi.org/10.1016/0006-3207(93)90324-T

Ispikoudis I, Lyrint zis G, \& Kyriakakis, S. (1993). Impact of human activities on Mediterranean landscapes in western Crete. Landscape and Urban Planning, 24, 259-2711. http://dx.doi.org/10.1016/0169-2046(93)90105-M

Liu, Y., Lv, X. J., \& Qin, X, S. (2007). An integrated GIS-based analysis system for land-use management of lake areas in urban fringe. Landscape and urban planning, 82, 233-246. http://dx.doi.org/10.1016/j.landurbplan.2007.02.012

Lu, D., Mausel, P., Brondízio, E., \& Moran, E. (2003). Change detection techniques. International Journal of Remote Sensing, 25, 2365-2401. http://dx.doi.org/10.1080/0143116031000139863 
McGarigal, K., Cushman, S. A., Neel, M. C., \& Ene, E. (2002). FRAGSTATS: Spatial Pattern Analysis Program for Categorical Maps. Computer software program produced by the authors at the University of Massachusetts, Amherst. Retrieved from http:/www.umass.edu/landeco/ research/fragstats/fragstats.html.

Manandhar, R., Odeh, I. O. A., \& Pontius, R. G. (2010). Analysis of twenty years of categorical land transitions in the lower Hunter of New South Wales, Australia. Agriculture, Ecosystems \& Environment, 135, $336-346$. http://dx.doi.org/10.1016/j.agee.2009.10.016

O’Neill, R. V., Krummel, J. R., Gardner, R. H., Sugihara, G., Jackson, B., \& DeAngelis, D. L. (1988). Indices of landscape pattern. Landscape Ecology, 1, 153-162. http://dx.doi.org/10.1007/BF00162741

Pignatti, S. (1993). Impact of tourism on the mountain landscape of central Italy. Landscape and Urban Planning, 24, 49-53. http://dx.doi.org/10.1016/0169-2046(93)90082-O

Riitters, K. H., Wickham, J. D., O’Neill, R. V., Jones, K. B., Smith, E. R., \& Coulston, J. W. (2002). Fragmentation of continental United States forests. Ecosystems, 5, 815-822. http://dx.doi.org/10.1007/s10021-002-0209-2

Reed, R. A., Johnson Barnard, J., \& Baker, W.L. (1996). Fragmentation of a forested Rocky Mountain landscape, 1950-1993. Biodiversity Conserve, 75 (3), 267-277.

Saura, S., \& Castro, S. (2007). Scaling functions for landscape pattern metrics derived from remotely sensed data: are their subpixel estimates accurate? ISPRS Journal of Photogrammetry and Remote sensing, 62, 201-216. http://dx.doi.org/10.1016/j.isprsjprs.2007.03.004

Su, W., Yang, F., \& Liu, S. W. (2011). Chongqing Mode. China Economic Publishing House. Beijing: China Economic Publishing House. http://dx.doi.org/10.1016/j.econmod.2010.11.016

Trani, M. K., \& Giles, R. H. (1999). An analysis of deforestation: metrics used to describe pattern change. Forest Ecology and Management, 114, 459-470. http://dx.doi.org/10.1016/S0378-1127(98)00375-2

Van Oort, P. A. J. (2007). Interpreting the change detection error matrix. Remote Sensing of Environment, $108,1-8$. http://dx.doi.org/10.1016/j.rse.2006.10.012

Wu, J. G. (2007). Landscape ecology_pattern, process, scale and hierarchy (2nd ed.). Beijing: Higher Education Press.

Yang, Q. Y. (2011). General reform of registry reform in Chongqing. Exploration, 11, 51-53.

Zhou, W. Z, Huang G. L, \& Cadenasso M. L. (2011). Does spatial con Figureuration matter? Understanding the effects of land cover pattern on land surface temperature in urban landscapes. Landscape and Urban Planning, 102, 54-63. http://dx.doi.org/10.1016/j.landurbplan.2011.03.009 